\title{
Name Christology, Divine Aseity and the I Am Sayings in the Fourth Gospel
}

\section{Abstract}

This article will examine the representation of divine aseity in the Fourth Gospel, particularly as this is developed through a "divine name" christology that is intertwined with the "I am" sayings. These sayings, which occur in both predicated and non-predicated form, together constitute one of the key devices by which the christology of the gospel is developed. While these are generally understood with reference to the statements of Isaiah 41:4 and 43:10, rather than

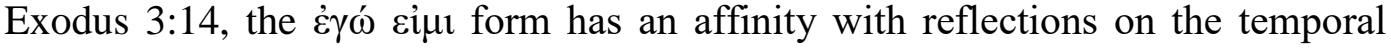
significance of the divine name disclosed to Moses that are elsewhere attested in Jewish tradition. This recognition opens the possibility that the "I am" sayings, even as they identify Jesus with the God of Israel, are intended as reflections on the properly theological "problem" of the incarnation, on what it means for a God who transcends time to be enfleshed and particularized within it. This is to say that the Name christology at work is as significant for how John would have his readers think about the identity of God as it is for how they are to think about the identity of Jesus.

The sayings render the identity of Jesus, as a human being located within time and place and whose substance is affected by these, as participating fully in the transcendent reality of God's own being. By taking temporal form, the God who transcends time, and whose existence is entirely self-subsistent, unites it to his own being. The author plays upon the apparent paradox in ways that are visible in the text and that are linked to his conceptions of salvation. It is precisely the capacity to unite death to the divine life without the terminal conditions of human contingency that ensures that Jesus can be the source of life for all who receive him. Hence, salvation is linked to the ontology of God, as he is in himself, and Johannine christology must be articulated in such terms.

Keywords: Gospel of John; Fourth Gospel; aseity; christology, ontology.

\section{Introduction}

Modern scholarship has rightly been attentive to the christological significance of the

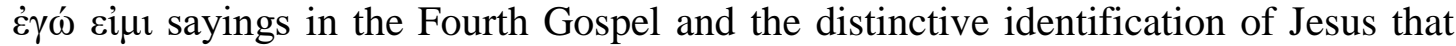
they constitute. ${ }^{1}$ It has been less attentive, however, to what we might label the

\footnotetext{
1 The most detailed engagements with the Johannine material are found in the monographs of David Mark Ball, "I Am" in John's Gospel: Literary Function, Background and Theological Implications (JSNT Supp 124. Sheffield: Sheffield Academic Press, 1996) and Catrin H. Williams, I am He: The Interpretation of 'Anî Hû in Jewish and Early Christian Literature (WUNT II: 113. Tübingen: Mohr Siebeck, 2000). Earlier and briefer discussions are found in Raymond E. Brown, The
} 
properly theological significance of the sayings and has, consequently, neglected some of the issues that can only be probed through the linguistic register of the theological discipline. Typically satisfied with a decision on whether, to what extent, or in which senses Jesus can be called "divine," modern biblical scholarship has not for the most part engaged with the implications that this might have for how we understand God and his attributes and how, in turn, this might speak to our understanding of soteriology. ${ }^{2}$ I would suggest that this has led to a neglect of certain elements of Johannine soteriology, particularly those of a less functional and of a more ontologically grounded sort. This contrasts with pre-modern exegesis of the text, ${ }^{3}$ which was often concerned to probe the properly theological significance of the incarnation, particularly the way that the Gospel renders divine aseity, now understood as an attribute of a triune God that grounds the work of salvation. "I am" is precisely a co-identification and its force lies not simply in its radical claim to the divine status of Jesus, but in the creaturely particularity that is now seen to be part of the self-naming identity of the One God. For those familiar with the Scriptures on which $\dot{\varepsilon} \gamma \omega \dot{~ \varepsilon i ̉ \mu ~ s a y i n g s ~ d r a w, ~ p a r t i c u l a r l y ~ i f ~ t h e s e ~ a r e ~ c o n s i d e r e d ~(c o n t r a ~ s o m e ~ r e c e n t ~}$ biblical scholarship) to include Exodus 3:14, the disruptive or disjunctional force of

Gospel According to John (Anchor Bible Commentary. New York, Doubleday, 1966), 533-38, Rudolf Schnackenburg, Das Johannesevangelium (HTKNT 4:II. Freiburg: Herder, 1971) 59-70 and Hans Klein, "Vorgeschichte und Verständnis der johanneischen Ich-bin-Worte," Kerygma und Dogma 33 (1987), 120-36.

Williams, I am He, 2-9, traces the details of the key research that lies behind these studies. Of these, we might note, in particular: Ethelbert Stauffer, Jesus: Gestalt und Geschichte (Bern: A. Francke, 1957), 130-46 \& 167-72; Hans Zimmerman, "Das absolute 'E $\gamma \omega ́$ cỉ $\mu$ als die neutestamentliche Offenbarungsformel," BZ 4 (1960), 5469, 266-76, and "Das absolute 'Ich bin' in der Redeweise Jesu," Trierer theologische Zeitschrift 69 (1960), 1-20; and Philip B. Harner, The "I Am" of the Fourth Gospel: A Study in Johannine Usage and Thought (Philadelphia: Fortress Press, 1970). Williams notes some key deficiencies in each study that her own seeks (successfully) to address. My own criticism is slightly different: all of the studies listed engage with the evidence in a diachronic fashion that avoids the use of later theological language such as aseity, and limits the conceptual lexicon of study to fragments or corollaries of the fuller concept.

${ }^{2}$ Richard Bauckham The Gospel of Glory: Major Themes in Johannine Theology (Grand Rapids: Baker, 2015) is an exception to this, but it does not deal with the category of aseity or with the concept of the divine attributes that are so important to earlier theological treatments of the gospel.

${ }^{3}$ The concept of aseity is prominent in, for example, Augustine's Tractates on the Gospel of John (notably 22:8-10). From the period of transition into modernity, it is also a highly developed theme in Calvin's commentary on John's Gospel and, from this, in his systematic thought. For a discussion of this, see Brannon Ellis, Calvin, Classical Trinitarianism and the Aseity of the Son (Oxford: Oxford University Press, 2012). Within modern scholarship on John, however, the theme is scarcely encountered. A telling exception is the excellent article by D. Jeffrey Bingham, "Christianizing Divine Aseity: Irenaeus Reads John," in The Gospel of John and Christian Theology (Grand Rapids: Eerdmans, 2008), 53-67. Even in the volume in which it is published, which is attentive to theological matters, this is the only article that deals with the divine attributes in relation to the incarnation and it does so principally with reference to an interpreter, rather than to the text itself. 
the allusion is not simply that they are placed on the lips of Jesus, but that they are linked thereby to contextual details that would never previously be predicated of this God. This can only rightly be analyzed using the lexicon and grammar of theology proper, brought to the text with sensitivity to the soteriological move that is made therein.

In this article, then, I want to explore some elements that have, I think, been overlooked by biblical scholarship. Specifically, I want to argue that the $\dot{\varepsilon} \gamma \omega$ si sayings identify Jesus with the God who is theologically described as a se ("of himself"). The incarnational union that the gospel renders is one in which this divine aseity is united to creaturely contingency, sharing its sufficiency with that which is in itself insufficient, mediating eternal life to frail and sinful creatures. It thus roots the redemptive significance of the incarnation in the unique ontology of God himself, in what he distinctively is, and not just what he does. Such a presentation of salvation is widely found in theological accounts, ${ }^{4}$ but is generally peripheral to biblical scholarship, which generally neglects the heuristic value of categories developed in later theology. At the same time, it requires us to understand divine aseity in positive and relational terms that are revealed in the gospel: it is as the one who is $a$ se that God gives himself to the world in the incarnation.

I will begin by offering some brief comments on aseity as a theological concept and reflecting on how these might relate to and inform the modern treatment of the $\dot{\varepsilon} \gamma \omega$ cíur sayings. Once I have done this, I will trace some of the distinctive associations that are made in the Scriptures that serve as background to the sayings, noting in particular some of the textual co-ordinations that appear to have taken place in their transmission; these require us to keep the disclosure of the divine name in Exodus 3:14 in view, alongside the principal background of the Deuteronomic and Isaianic "I am he" sayings. This is well-trodden ground in scholarship, but my examination will approach the details with a subtly different question to the one commonly asked: not, "How do these details contribute to the representation of Jesus in the Fourth Gospel?" but "How do they prepare us for the representation of God in the Fourth Gospel?" By re-associating these concepts with a mortal being, whose personal narrative appears to involve a level of ontological contingency within the created order, the Gospel turns the challenge of conceptualizing the incarnation of the eternal, infinite God into a basis for soteriology. This will be studied in the third and fourth sections of the article, which will deal with John's Gospel itself.

\section{On Aseity}

As is the case with most theological language, the term "aseity" has a wider philosophical usage, but for our purposes what matters is the theological usage of the word and what it seeks to name. At the most basic level, it articulates the truth that God is "of himself" or, to put this in slightly fuller terms, that "In every respect, God

\footnotetext{
${ }^{4}$ As well as the works listed above, we might note the place of the concept in Barth's Church Dogmatics. For a close examination of this, see Brian D. Asbill, The Freedom of God for Us: Karl Barth's Doctrine of Divine Aseity (London: Bloomsbury T\&T Clark, 2016).
} 
is of himself God." ${ }^{5}$ In positive terms, this is an affirmation of the perfection and plenitude of God but, as Webster notes, one of the immediate dangers that attends such an assertion is that it is effectively debased by setting it too quickly (or even exclusively) in contrast with its opposite, reducing it to its negative corollaries: God's aseity means that his existence is non-contingent, but to describe God as noncontingent is less than describing him as $a s e$. Webster traces this distinctively modern "pathology" 6 through various treatments of the concept and identifies therein a loosing of aseity from its proper mooring in the identity of God and a reattachment to more abstract concepts of deity: aseity becomes part of a logical argument about existence (and the necessity of a first mover), rather than an assertion made about who the triune God is.

Aseity becomes less an affirmation of the underived beauty and goodness of God, and more a property which must be ascribed to deitas if it is properly to fulfil its function of supporting the contingent. ${ }^{7}$

Interestingly, as an echo of this, Webster notes that Schleiermacher (followed by Tillich) considered aseity to be nothing more than a combination of the notions of

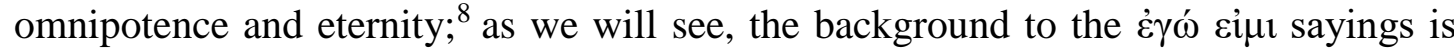
generally understood today in these very categories and it is important that we recognize them to fall short of the fuller classical notions of aseity. Instead, a proper treatment of the attribute "tries to indicate God's identity; it is not a definition of God but a gesture towards God's objective and self-expressive being." "9

As such, the theological traditions of both Judaism and Christianity have been deeply sensitive to the association between the concept of aseity and the various points in Scripture where some form of the expression "I am" is used as a statement precisely of divine identity. ${ }^{10}$ These involve an act of self-naming that asserts the uniqueness of God and the necessity of his being to the existence of other things, by communicating who God is. Despite occupying the foreground of discussion about aseity, the eternity of God and the contingency of other things upon his creative activity are really derivations from this central assertion of divine identity, rendered as contrasts to the creaturely realities of mortality and contingency. This asserts not just divine self-subsistence, but divine goodness; from his own fullness, God gives himself lovingly in creative, providential and redemptive activity. Because the one who names himself "I am" is, the cosmos is, and it is good (Genesis 1:31). ${ }^{11}$

Philo provides an interesting example of thinking about divine aseity that affirms the very points we have just outlined as features of early Jewish thought:

\footnotetext{
${ }^{5}$ John B. Webster, "Life in and of Himself," in his God Without Measure: Working Papers in Christian Theology. Volume 1: God and the Works of God (London: Bloomsbury T\&T Clark, 2016), 13-28. The quotation is taken from p.13.

${ }^{6}$ Webster, "Life in and of Himself," 18.

${ }^{7}$ Webster, "Life in and of Himself," 18.

${ }^{8}$ Webster, "Life in and of Himself," 17.

${ }^{9}$ Webster, "Life in and of Himself," 13.

${ }^{10}$ See Ellis, Calvin, Classical Trinitarianism and the Aseity of the Son, 202-04.

${ }^{11}$ Augustine is sensitive to this implication of aseity. See his De Doctrina Christiana, I:32, which reflects upon the giving of the divine name in Exodus 3:14: "Because he is good, we exist."
} 
We all know that before the creation of the world, God was sufficient unto Himself, and that after the creation He remained the same, unchanged. Why then did he make the things that were not? Why, save because $\mathrm{He}$ was good and bountiful (Mut. 46). ${ }^{12}$

This is noteworthy, for it highlights that the deployment of the concept in Jewish literature from the Second Temple period reflected this fuller, more positive and relational concept of aseity, rather than merely its logical negative derivations. ${ }^{13}$ This is all the more striking in the context of Philo's writings, since he is so preoccupied with the philosophical or logical questions that attend talk of God.

A significant adaptation occurs in Christian theology, though, as aseity comes to be articulated in trinitarian terms. John's Gospel, and particularly the description of the Son as having life in himself $(5: 26)$ plays an important role in the theological traditions (see footnote 3, above), though one heavily debated. ${ }^{14}$ For our purposes, what is most significant about the shift is twofold. First, it reflects a fundamental conviction that if Jesus is identified not just "with" but "as" God, then the attributes of God considered intrinsic to his being must be sustained within the incarnation. This, obviously, creates conceptual or linguistic challenges: how are we to speak of one whose self-subsistent being transcends time and space becoming (John 1:14) finite mortal flesh? These challenges, however, become the grounds for both creational and soteriological reflection: in the union of the created and uncreated, the temporal and the eternal, the mortal and the immortal, lies the hope of eternal life. ${ }^{15}$ Second, it

${ }^{12}$ The extract is discussed by Peter Frick, Divine Providence in Philo of Alexandria (TSAJ 77. Tübingen: Mohr Siebeck, 1999), 62. Interestingly, Frick also notes that in Legum Allegorice 3:73 the name "God" is attached particularly to the "goodness" $\dot{\alpha} \gamma \alpha \theta$ ó $\rceil \tau \tau \varsigma \varsigma$ of the "cause of all" (i.e., First Cause).

${ }^{13}$ That such positive assertions of the concept are detectable in early Judaism and in the Scriptures of Old and New Testaments themselves is a thread running through Katherine Sonderegger's sensitive Systematic Theology, Volume 1: The Doctrine of God (Minneapolis: Fortress Press, 2015).

${ }^{14}$ Ellis, Calvin, Classical Trinitarianism and the Aseity of the Son, in toto, engages with the debates around the significance of the Father's granting the Son to have life in himself. Ellis himself constructively develops Calvin's strong assertion of the Son's aseity (197-226).

${ }^{15}$ This is not just a matter of eternal life as salvation, but more basically as the goal of creation. The words of Athanasius reflect this, and the place of Johannine vocabulary within these should not be overlooked:

And the cause why the Word of God really came to created beings is truly wonderful, and shows that things should not have occurred otherwise than as they are. For the nature of created things, having come into being from nothing, is unstable, and is weak and mortal when considered by itself ...

... But being good, he governs and establishes the whole world through his Word who is himself God, in order that creation, illuminated by the leadership, providence, and ordering of the Word, Creation may be able to remain firm, since it shares in the Word who is truly from the Father and is aided by him to exist, and lest it suffer what would happen, I mean a relapse into non-existence, if it were not protected by the Word. (C.Gentes 3.41) 
presses the category of aseity back into the self-subsistence of a God now considered to enjoy an eternal internal fellowship; that is, it presses the category back into the eternal inner relations of Father, Son and Spirit. God's sharing of himself with the cosmos - creatively, providentially and redemptively - is an overflowing of a perfect love that needs nothing beyond itself.

What does this mean for our engagement with the Fourth Gospel? Principally, it means that we have to be attentive to both the positive and the contrastive significance of aseity, as a concept; it is not simply non-contingency, or eternity understood in graded contrast to temporal vulnerability, but rather an underived fullness of life that is lovingly shared with a cosmos that can only ever enjoy life derivatively. Consequently, we need to be attentive to the personal and relational overtones to the $\dot{\varepsilon} \gamma \omega \dot{\varepsilon}$ ciut sayings and not just abstractly to the attributes of eternity or omnipotence of which they may speak. As we shall see, the contrast between the contingency or earthly elements and the non-contingency of the divine Son is important to the soteriology of the Fourth Gospel, but it is a contrast that emerges from more basic relationships. The relational overtones may reflect the communication of Father and Son - what the tradition would come to understand as belonging to the inner life of the Trinity - but also the communication of God's underived life to the world. That is, the relational element is both immanent and economic.

\section{Backgrounds and Contexts.}

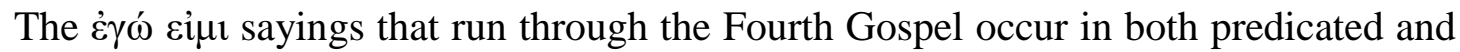
unpredicated (absolute) forms and there is a general scholarly recognition that the two sets of sayings are intended as interlaced literary devices by the evangelist. ${ }^{16}$ This has been an important factor in the discussions about the backgrounds to these sayings, since any theory must be capable of explaining the absolute sayings, and not just the predicated ones. In other words, backgrounds must be identified that also deploy $\dot{\gamma} \gamma \dot{\omega}$ Eij $\mu \mathrm{in}$ an absolute and non-predicated form. Consequently, scholars have typically seen the principal influence on the $\dot{\varepsilon} \gamma \omega \dot{~ \varepsilon i \mu t ~ s a y i n g s ~ n o t ~ i n ~ t h e ~ r e v e l a t i o n ~ o f ~ t h e ~ d i v i n e ~}$ name in Exodus 3:14, where the phrase does not occur in absolute form, but in the use

Translation, Robert Thompson, Athanasius: Contra Gentes and De Incarnatione (Oxford: Clarendon Press, 1971).

In modern theology, the linked creational and soteriological significance of aseity, now understood with respect to the death of Jesus, is elaborated in Eberhard Jüngel, Gott als Geheimnis der Welt: zur Begründung der Theologie des Gekreuzigten im Streit zwischen Theismus und Atheismus (Tübingen: Mohr Siebeck, 1977), 248-307. Jüngel represents perishability (Vergänglichkeit) as an ontological simile of "nothingness" (Nichts); God's being is "Auch-sich-heraus-Gehen in das Nichts" (303). His going into death, then, becomes a creative act of victory, as his life is poured into the nothing from which he creates.

${ }^{16}$ This is really the core claim of Ball, "I Am" in John's Gospel, articulated particularly on page 15 . 
of $\dot{\varepsilon} \gamma \omega \dot{~ \varepsilon i j \mu ~ i n ~ D e u t e r o n o m y ~ 32: 39 ~ a n d ~ a t ~ a ~ n u m b e r ~ o f ~ p o i n t s ~ i n ~ I s a i a h, ~ n o t a b l y ~ 43: 10, ~}$ 46:4, and a number of further texts in Deutero-Isaiah, ${ }^{17}$ where it translates אני הוא (and in some cases אני יהוה). It is worth probing this a little further, however, as a closer examination suggests that in the Scriptures and traditions the Gospel draws upon, there was some coordination of the Deuteronomic and Isaianic sayings with the divine name.

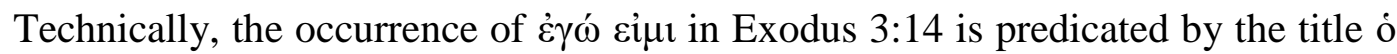
ळv, which renders the second occurrence of אהיה, in the famous articulation of the divine identity, אהיה אשר אהיה.

ויאמר אלהים אל משה אהיה אשר אהיה ויאמר כה תאמר לבני ישראל אהיה שלחני אליכם

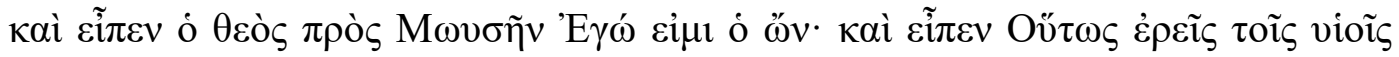

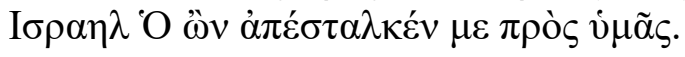

God said to Moses, "I AM WHO I AM." He said further, "Thus you shall say to the Israelites, 'I AM has sent me to you."” (Ex 3:14)

Deuteronomy 32:39 and the various Isaiah texts noted above, however, use the expression in absolute form, allowing them to function as a background to the absolute sayings in John. A cluster of texts in Isaiah ${ }^{18}$ also use the expression in its predicated form and hence the blend of predicated and absolute forms encountered in the gospel is paralleled quite broadly in the prophet. All of this points to these sayings as constituting the principal, or immediate, background to the $\dot{\varepsilon} \gamma \omega \dot{~ \varepsilon i j \mu ~}$ sayings of John.

The texts in Deuteronomy and Isaiah use the expression in connection with the uniqueness of God's identity. ${ }^{19}$ The first two texts can be read fairly straightforwardly in order to highlight this, with the key points set in italics:

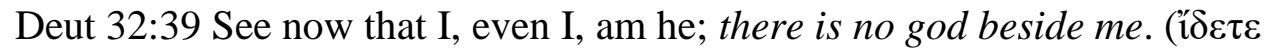

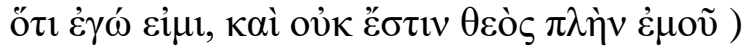

I kill and I make alive; I wound and I heal; and no one can deliver from my hand.

Isaiah 43:10 You are my witnesses, says the LORD,

${ }^{17}$ Isaiah 43:10, 25; 45:8, 18-19, 22; 46:4, 9; 51:12; 52:6. Occasionally, as in 43:25, the form אנכי הוא is encountered. Interestingly, in 43:25, the $1^{\text {st }}$ person pronoun is

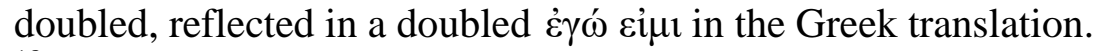

${ }^{18}$ For example, Is. 48:12, 17; 56:3.

19 This highlights a problem in the argument of M. David Litwa, We Are Being Transformed: Deification in Paul's Soteriology (Berlin: De Gruyter, 2012). Litwa consistently approaches the concept of deity as something associated with attributes such as eternity, and is scornful of the weight placed by biblical scholarship on the articulations of monotheism in "Second Isaiah" (see, esp, 230). Litwa's work suffers from the same error that Bauckham pinpoints in his essay God Crucified (Carlisle: Paternoster, 1998): he fails to see that the identity question-"Who is God?"-is more basic to the texts than the ontological one ("What is deity/divinity?"). Litwa is consistently blind to the significance of the divine name as a label of identity, not just in Isaiah, but in the Old Testament and Second Temple texts broadly. 
and my servant whom I have chosen,

so that you may know and believe me

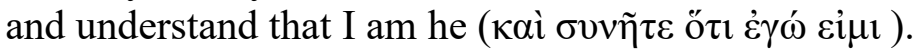

Before me no god was formed,

nor shall there be any after me.

Isaiah 46:4-5 requires a little more comment as the Greek departs from the Hebrew by adding an additional غ̇ $\gamma \omega \dot{~ \varepsilon i ̉ \mu ~ c l a u s e, ~ w h i c h ~ I ~ h a v e ~ h i g h l i g h t e d ~ i n ~ b o l d ~ b e l o w: ~}$

Hebrew (MT):

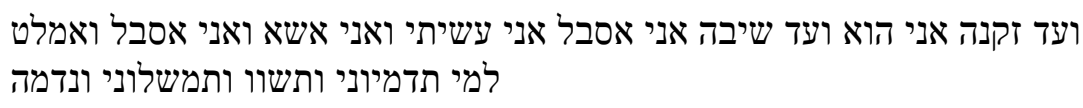

Even to your old age I am he; even when you turn gray I will carry you.

I have made, and I will bear; I will carry and will save.

To whom will you liken me and make me equal, and compare me, as though we were alike?

Greek:

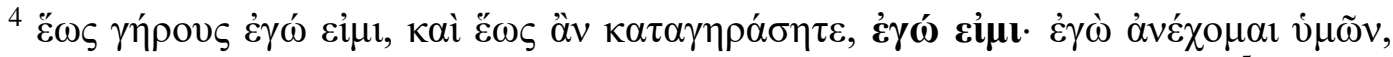

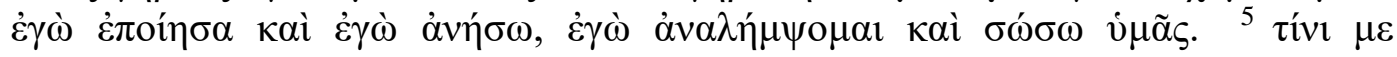
$\dot{\omega} \mu о \imath \omega ́ \sigma \alpha \tau \varepsilon ; i ́ \delta \varepsilon \tau \varepsilon \tau \varepsilon \chi \nu \alpha ́ \sigma \alpha \sigma \theta \varepsilon$, oi $\pi \lambda \alpha \nu \omega ́ \mu \varepsilon v o t$.

${ }^{4}$ Even to old age I am (he); and until you have grown old, I am (he): I lift/carry you, I have made, and I will relieve, I will take up and save you. ${ }^{5}$ To whom have you compared me? See, consider, you that go astray.

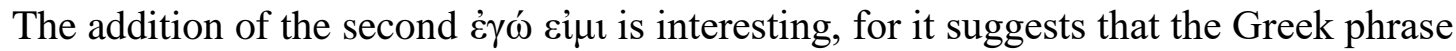
had become established as a designation of the divine identity of the speaker, paralleling the significance of the Hebrew אני הוא that it generally translates, and could

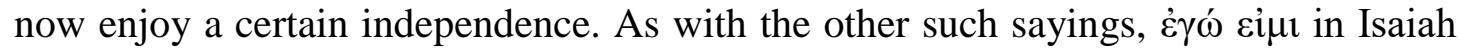
46:4-5 is linked to an emphasis on divine uniqueness: "To whom have you compared me? See, consider, you that go astray."

In both Isaiah 43:10 and 46:4, the dual temporal dimension of pre-existence and eschatological ultimacy is an important part of God's uniqueness. He existed before any other god and promises his presence into his servant's old age because of his own imperviousness to the ravages of time. This is further reflected in 48:12, where the $\dot{\varepsilon} \gamma \omega \dot{\varepsilon}$ cì form is encountered in combination with another phrase that has already separately been used in 44:6, 'the first and the last', serving as an expression of selfidentity by the LORD, the King of Israel. ${ }^{20}$

${ }^{20}$ Isaiah 44:6 reads "I am the first and I am the last; besides me there is no god. 7 Who is like me?" Interestingly, the preceding verse (44:5) plays on the idea of names: 


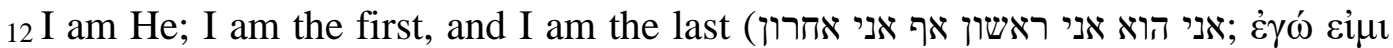

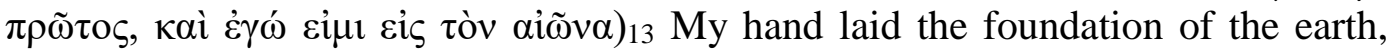
and my right hand spread out the heavens.

The phrase thus points to the unique eternality and sovereignty of God, and this has been highlighted by scholarly examination of the sayings. Catrin Williams, whose study remains the most detailed and important analysis of the אני הוא sayings and their interpretation, concludes that the expression, "serves as a declaration of the unique sovereignty of Yahweh" and marks his unique status as the "eternally active God ... the Creator of all things." ${ }^{21}$ This is surely correct, but it needs to be balanced by a proper recognition that the principal concern of the texts is with divine identity; the status implications are derived from this. Williams's work, which is here broadly in line with other scholarship on the sayings, reflects the same shift that we noted in Schleiermacher and Tillich.

Demonstrative of this concern with identity, it is significant that most of the $\dot{\varepsilon} \gamma \omega$ ' ciju statements in Isaiah are closely associated with occurrences of the divine name. It is "the LORD" who so speaks and designates himself in this way, and the connection with the name is sometimes elaborated in the wider context. Isaiah 43:10, for

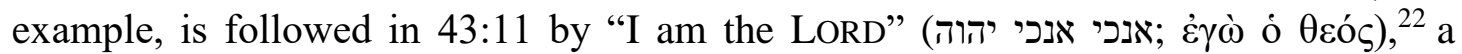

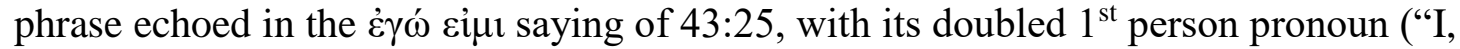

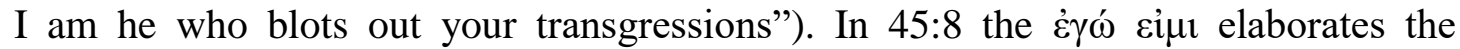
pronoun in אני יהוה בראתיו , "I, the LORD, have created it," transforming it to "I am

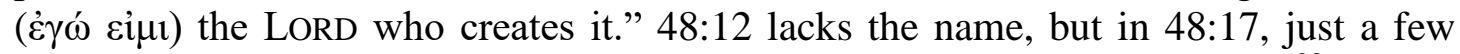
verses further on, it is explicitly "the LORD" who says "I am your God." ${ }^{23}$ Similar observations can be made with most of the occurrences. So, the formula comes to have a particular association with the divine name.

This alone would be significant for the interpretation of the $\dot{\varepsilon} \gamma \omega \dot{\omega}$ cij sayings in John: the expression evokes the divine name by association, even if it does not itself represent the name. It is, though, all the more striking when we note that the language and imagery used in these sayings has a measure of overlap with later Jewish treatments of the divine name. In Targum Pseudo Jonathan, for example, we encounter a modestly elaborated version of the disclosure of the name in Ex 3:14 ("I am what I am and I will be what I will be"24) and a more significantly elaborated version of the "I am he" statement of Deut 32:39:

This one will say, "I am the LORD's," another will be called by the name of Jacob, yet another will write on the hand, "The LORD's," and adopt the name of Israel.

${ }^{21}$ Williams, I am He, 304.

${ }^{22}$ Interestingly, the Greek does not here render the doubling of the first person

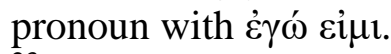

${ }^{23}$ What the LORD says here changes in the translation to Greek. "I am the LORD your God" becomes simply "I am your God."

24 3:14b: adds דהוינא. 3:14a: "He who said and the world was, (who) said and everything was." See the excellent discussion in Robert J. Wilkinson, Tetragrammaton: Western Christians and the Hebrew Name of God. From the Beginnings to the Seventeenth Century (Leiden: Brill, 2015), 182-3. 
Behold now, that I am he who am, and was, and will be, and there is no other God beside me: I, in my Word, kill and make alive;

אנא הוא דהוויי והוית ואנא הוא דעתיד למהוי ולית אלקא חורן בר־מיני אנא במימרי ממית ומחי מחית ישית ישית יתית מחיתי ית עמא בית ישראימרי ממית

The elaboration of the "I am he" statement in this verse is particularly interesting because it appears to reflect a deliberate interpretation of the saying in the light of Exodus 3:14.

Those familiar with the book of Revelation will immediately notice the parallels of this elaboration with the divine epithets used in that book; it is important to recognize the extent to which these provide evidence that what is found in the targum is a tradition of divine-name reflection that can be traced back into Second Temple Judaism. The parallels between Revelation and the Targum Pseudo Jonathan are constituted by a pattern of "Alpha and Omega"/"First and Last" sayings that run through the book, within which both God and Jesus are identified as the speakers:

Rev. 1:8 "I am the Alpha and the Omega," says the Lord God, who is and who was and who is to come, the Almighty. (God)

Rev. 1:17-18 When I saw him, I fell at his feet as though dead. But he placed his right hand on me, saying, "Do not be afraid; I am the first and the last, and the living one. I was dead, and see, I am alive forever and ever; and I have the keys of Death and of Hades. (Jesus)

Rev. 2:8 "And to the angel of the church in Smyrna write: These are the words of the first and the last, who was dead and came to life (Jesus)

Rev. 21:6 Then he said to me, "It is done! I am the Alpha and the Omega, the beginning and the end. To the thirsty I will give water as a gift from the spring of the water of life. (God)

Rev. 22:13 I am the Alpha and the Omega, the first and the last, the beginning and the end." (Jesus)

In the case of Revelation 1:8 and 1:17, these sayings are also introduced with the $\dot{\varepsilon} \gamma \dot{\omega}$ ciju formula, though in predicated form. The first is nearly identical to Targum Pseudo-Jonathan Deut 32:39; the second parallels Isaiah 44:6/48:12.

The extent to which this embodies reflection on the divine name emerges from closer examination of the pattern. The use of "Alpha" and "Omega" as parallels for "first and last" reflects the location of these letters in the Greek alphabet. But they are also the vowels used in the word Adonai, used in place of the divine name when Scripture was read, the vowels of which would later be super-imposed on the Tetragrammaton in the MT. What this suggests is an inner-biblical ${ }^{25}$ co-ordination of

25 This terminology is associated with a movement in biblical scholarship that analyzes the way that Scriptures are read, interpreted and reworked within the biblical texts themselves in ways that reflect the principles of interpretation articulated in the Rabbinic middot. Most of the relevant scholarship has been developed in the study of the Hebrew Bible and Second Temple texts. The approach was pioneered by Michael 


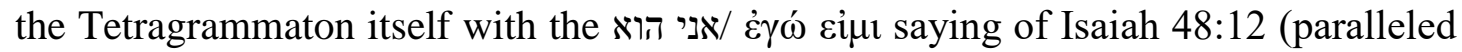
by 44:6). At this stage in the argument the key observation is simply that Revelation provides supporting evidence that what we encounter in the text of Targum Pseudo Jonathan reflects traditional and probably widespread ways of reflecting on the association of the Tetragrammaton and the verb "to be" (and the specific forms encountered in Exodus 3:14), and that these appear to have been coordinated with the

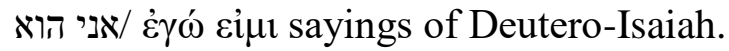

The point is an important one, for it serves to balance the observations made by Williams concerning the limited overlap of the interpretation of Exodus 3:14 with the Isaianic אני הוא sayings. Williams rightly highlights the extent to which there is a distinctive pattern of development for each through their translations and interpretations, directed towards particular strategies for asserting monotheism. This becomes important to her eventual conclusion that the אני הוא sayings have their own "distinctive character and theological import" that is not identical to the

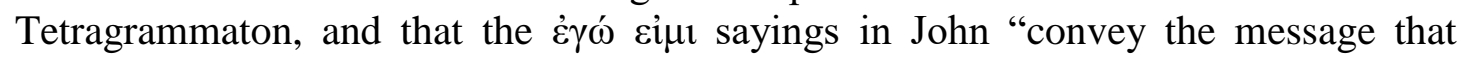
God's saving powers are made visible and accessible in Jesus." 26 Williams' work is careful and undoubtedly correct, but the evidence of Targum Pseudo-Jonathan and Revelation also confirms that these two distinct traditions within Judaism were coordinated and that this was exploited for Christological purposes within early Christian theology.

One further observation on the targumic material can now be made. The "I am he" sayings occur in close proximity to significant uses of the word Memra (מימר, "Word"), often connected to the related works of creation and providence. This can be seen in the translation of Deuteronomy 32:39 above: "I, in my Word, kill and make alive." More notable examples of this can be found in the targumic translations of Isaiah 45:12 and 48:13, in each of which it is "by my Memra" (במימרי) that God stretches out the heavens and creates the earth. The possibility that the Memra of the targums provides some background to the use of Logos in John 1 has received fresh attention of late, in studies by John Ronning and Daniel Boyarin among others. ${ }^{27}$ In Ronning's case, Memra is understood as a straight circumlocution for God; in Boyarin's, the use of the word as a substitute for the divine name becomes the basis for a developing Jewish binitarianism, in which the Memra is seen to have distinct identity and existence. The observation I make here is quite specific and doesn't rely

A. Fishbane, "Revelation and Tradition: Aspects of Inner-Biblical Exegesis," Journal of Biblical Literature, 99 (1980), 343-61. George Brooke's research on the use of Scripture at Qumran has highlighted the extent to which the Rabbinic codes reflect earlier (i.e., Second Temple) practices. See his Exegesis at Qumran: 4QFlorilegium in its Jewish Context (Sheffield: JSOT Press, 1985). One of the best entry points into the methodology and its published literature is found in the introduction of William A. Tooman, Gog of Magog: Reuse of Scripture and Compositional Technique in Ezekiel 38-39 (Tübingen: Mohr Siebeck, 2011). The approach has not yet had as significant an impact on New Testament research as it should have; the work of Susan E. Docherty, The Use of the Old Testament in Hebrews: A Case Study in Early Jewish Interpretation (WUNT II:260. Tübingen: Mohr Siebeck, 2009) is a notable exception that draws seriously on the relevant scholarship.

${ }^{26}$ Williams, I am He, 303.

${ }^{27}$ John Ronning, Jewish Targums and John's Logos Theology (Grand Rapids: Baker, 2010); Daniel Boyarin, "The Gospel of the Memra: Jewish Binitarianism and the Prologue to John" Harvard Theological Review 94 (2001), 243-84. 
on the validity of Ronning's or Boyarin's arguments as a whole: it is simply that the

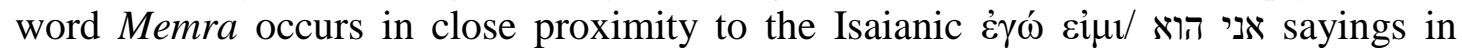
which God is represented as eternal, and its association with creation is connected to this representation of God's pre-existence. This is suggestive, at least, of the particular combination of devices (Logos and I Am sayings) that we encounter in John.

Several specifically theological points may now be isolated from the discussion above. First, while the disclosure of the divine name in Exodus 3:14 and the

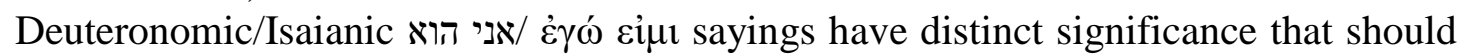
not be collapsed, they are coordinated in the traditions, in such a way that the significance of each becomes identified with the other. This is particularly important in relation to the most basic assertions of divine identity: the one who is named by the Tetragrammaton is the same one who proclaims himself unique in the אני הוא sayings.

Second, the coordination of the traditions means that the divine name is associated

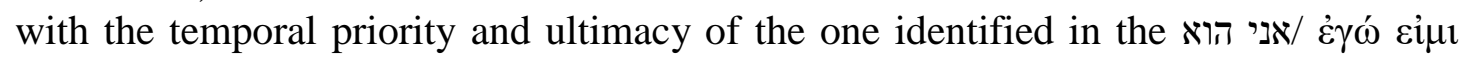
sayings. This is not simply a matter of asserting the eternity of God, but of asserting this to be uniquely a predicate of God, one that defines his relationship to all that is outside of himself. All of his relations ad extra are relations between one who is eternal and that which is temporal. By asserting that God is uniquely First and Last, this is affirmed in a way that connects it to his very name: אהיה אשר אהיה. What must not be overlooked is that this disclosure of identity is also an act of personal communication: YHWH gives his name, even as he gives himself.

Third, this move ultimately requires the use of the term aseity to designate the character of God's relationship to the temporal cosmos, not merely in its temporality, but in its entirety. The priority and ultimacy of God mean that his existence must be considered independently of the creaturely cosmos; it is not contingent upon the cosmos. God is $a$ se, in a way that must therefore be considered unique. The cosmos is contingent upon his reality, as Creator and Provider, and his reality is not dependent upon its. But precisely because of the character of his aseity, that is an underived fullness that may be described as 'good', the temporal cosmos is: God, in his selfsubsistence and fullness has chosen to share himself creatively.

All of this is intended to stress that the reader who approaches the Fourth Gospel through its invoked textual backgrounds brings to the text a particular identification of the God of Israel, one that is associated with a divine name that speaks of a particular relationship to the created temporal cosmos, which is in turn the basis for the monotheistic claim. To set such language on the lips of Jesus is not just to radically identify the man with God, but to shockingly identify God with the man.

\section{The Prologue of John's Gospel: The Recasting of Divine Identity and the Re-placing of the Divine Name}

The prologue to the Gospel is the necessary entry point into the wider book and it prepares its reader to expect that their way of thinking about God will be altered by

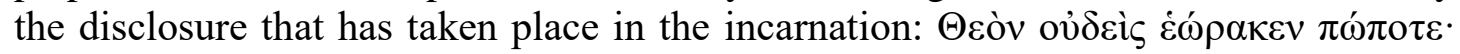

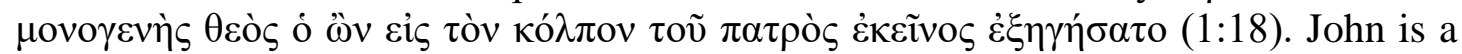
highly structured and complex text, in which various literary devices are deployed in 
service of the theology of the writer(s). Assumptions or conclusions concerning the redactional history of the text play some part in how we understand these devices to interact, but even approaches that operate with a more complicated account of the development of the text acknowledge the theological continuity of the various stages of authorship, allowing us to consider the final form of the text without having to make too many assumptions about how this relates to its prior stages. ${ }^{28}$ The prologue to the Gospel (1:1-18) is sometimes considered to represent a late addition to the text, but the lexical and thematic connections with the wider gospel text are striking; the sensitive reader will find that this section of text anticipates what is to follow, and what follows will often appear to echo the prologue. ${ }^{29}$

The prologue, of course, establishes a strong identification of Jesus with God, one

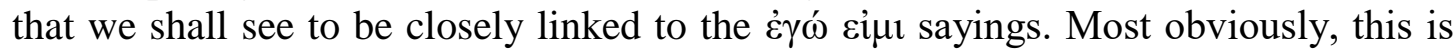
done through the opening declaration, 'In the beginning was the Word, and the Word

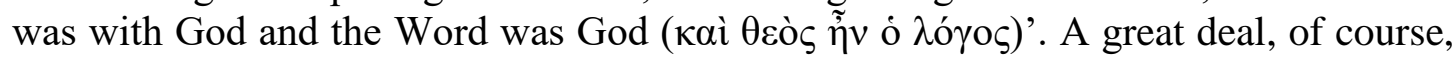
has been written on the significance of the term $\lambda$ ó $\gamma$ o $\zeta$ and its possible backgrounds. ${ }^{30}$ While there is little need to rehearse the details of those discussions here, a key point must be noted. Although scholars have often sought to isolate a single background or parallel as the key influence-Wisdom, Torah, Memra or Philo's appropriation of Stoic terminology - there is a growing recognition in studies of the Hebrew Bible and early Judaism that the imagery in question develops in an associative and not a competitive way, and this must be factored into the evaluation of the imagery here. ${ }^{31}$ That is to say, the use of $\lambda$ ó $\gamma$ os may deliberately invoke a complex of texts and traditions involving Wisdom and Torah and attempts to narrow this to one element of this complex, perhaps associated with a particular school, are misguided. In light of what we saw in the previous section about the close association between the Memra and the divine name in the targums, this associative dimension is suggestive; it leads us to expect some occurrence of the divine name in the near context. ${ }^{32}$

${ }^{28}$ The preoccupation with source-criticism has generated a massive literature on the Fourth Gospel, especially in relation to the Prologue, which has often been seen as an adaptation of an earlier hymn. For relevant bibliography, see Craig S. Keener, The Gospel of John (Grand Rapids: Baker, 2003), 105-15, 333-37. An excellent, if now dated, list is also found in Ed L. Miller, Salvation History in the Prologue of John: The Significance of John 11:3/4 (Leiden: Brill, 1989), 2, ftnote 3. More recently, Boyarin, "The Gospel of the Memra," 262-68, lists (and engages with) the key works. In addition to the works listed above, see also Peter J. Williams, "Not the Prologue of John," JSNT 33 (2011) 375-386.

${ }^{29}$ See Martin Hengel, "The Prologue of the Gospel of John as the Gateway to Christological Truth," in Richard Bauckham and Carl Mosser, eds, The Gospel of John and Christian Theology (Grand Rapids: Eerdmans, 2008), 265-94; Richard Bauckham, The Testimony of the Beloved Disciple (Grand Rapids: Baker), 271-83.

${ }^{30}$ Any good commentary will provide details of the literature; Boyarin, "Gospel of the Memra" and Ronning, Jewish Targums also list the relevant works.

${ }^{31}$ See the articles by Michael V. Fox and Stuart Weeks in Mark R. Sneed, ed., Was There a Wisdom Tradition? New Prospects in Israelite Wisdom Studies (Atlanta: SBL Press, 2015): Fox, "Three Theses on Wisdom," 69-86; Weeks, "Wisdom, Form, and Genre," 161-178.

${ }^{32}$ When set within this observation, the recent renewal of interest in the theory that the Memra (Word) of the Aramaic targums provides a distinctive parallel to the $\lambda$ ó $\gamma \circ$ takes on fresh significance, for as we have seen, the Memra is closely associated with 
Given what we saw in our discussion of aseity, it is significant that the Word is identified in both temporal and relational terms: he was with God ( $\pi \rho$ ò $\varsigma$ tòv $\theta \varepsilon o ́ v)$ in the beginning. Only once this prior relationship has been described does the Prologue recount the creational role of the Logos (1:3-4). The link to John the Baptist's testimony should not be overlooked:

John testified to him and cried out, "This was he of whom I said,

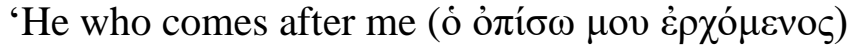

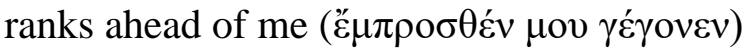

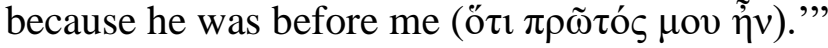

This is reminiscent of the versions of John's words that are encountered in the Synoptics, but here the theme of status is tied quite specifically to temporal priority: Jesus was "before" John and this is the grounds for his superior status. It is difficult not to hear an anticipation of John 8:58 ("Before Abraham was, I am") in these words and, as with that text, this one combines the temporal elements in a quite striking way.

It is important that this is recognized when the parallels between the representation of the Logos and that of Wisdom, Torah or Memra are discussed. ${ }^{33}$ We must be sensitive to the fact that here they are used to differentiate the status and identity of individual human beings, of two cousins whose identities and significance could, if viewed without such perspective, be seen as nothing more than accidents of history. As readers, we are made aware that the one of whom we read is Jesus of Nazareth, the cousin of John the Baptist, who had been crucified outside Jerusalem under Pontius Pilate. There is, in other words, a historical and personal particularity now identified as the one who "was $\pi \rho \tilde{\omega} \tau$ ó $\zeta$ " and this identification sets him in a category apart, at once from other contemporary individuals held to be important (such as John), and from other figures associated with the divine work of creation (such as Wisdom or Torah). This personal dimension is only fully appreciated when we consider the revelatory significance attached to the Logos. The Word that is identified with the otherwise unseen God is the one who makes him known (1:18) and this personal individuation will come to be specifically defined in the representation of Jesus of

the divine name, particularly in relation to creation. Jarl Fossum, The Image of the Invisible God: Essays on the Influence of Jewish Mysticism on Early Christology (Göttingen: Vandenhoek \& Ruprecht, 1995) notes that the same tendency to personify that is seen in relation to Wisdom and Memra is seen in relation to the Name in Second Temple texts such as Jubilees:

... the glorious and honoured and great and splendid and amazing and mighty Name which created heaven and earth and everything together (Jub 36:7).

Recognizing that such imagery functions associatively rather than competitively allows us to see name traditions as invoked alongside the other backgrounds to the Prologue. This has implications for how we understand the coherence of the Prologue

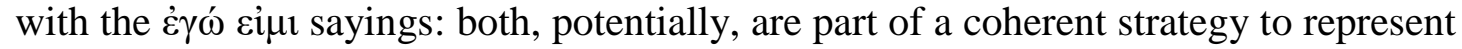
Jesus by allusion to a complex of traditions about the agency of God in creation. That is, he is identified with the thing that most particularly renders the unique identity of the creating God: his name.

${ }^{33}$ For the detail, see Boyarin, "The Gospel of the Memra." 
Nazareth. ${ }^{34}$ The parallels with Wisdom, Torah or Memra reach the limits of their potential significance when "the Word becomes flesh."

Unsurprisingly, given what we have noted about the associative deployment of the Memra, the prologue also provides us with the first use of the word obo $\mu \alpha$ in John's Gospel. In 1:12, we read:

But to all who received him, who believed in his name, he gave power to become children of God.

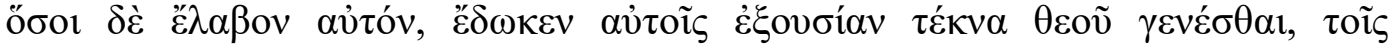

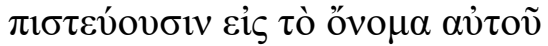

The significance of this reference to those who "believed in his name" should not be underestimated. As the most basic level, it points to an acknowledgement of the identity of Jesus, but the combination of concepts is one that draws upon traditional affirmations of trusting in the One God:

Our heart is glad in him, because we trust in his holy name. (Psa. 33:21)

Who among you fears the LORD and obeys the voice of his servant, who walks in darkness and has no light,

yet trusts in the name of the LORD and relies upon his God? (Is. 50:10)

The latter passage, in particular, provides a suggestive background to John 1:12, given the range of lexical overlaps (darkness, light, name).

John 1:12 is, in fact, the first of 25 occurrences of "name" in John. The distribution and referential significance of these is interesting. As Joshua Coutts has recently noted in his dissertation on the topic: "Of the twenty-five uses of ovo $\mu \alpha$ in GJohn, twelve refer to Jesus' name, and eight to the Father's Name (divine Name) $(5.43 ; 10.25 ; 12.13 ; 12.28 ; 17.6,11-12,26) .{ }^{35}$ Of the occurrences of the word in relation to the name of Jesus, another two $(2: 23,3: 18)$ present it as the object of the verb $\pi \imath \tau \tau \varepsilon v ́ \omega$, developing the association that we have seen to be at work in 1:12. The name of Jesus is represented as the object of faith in the same way that the name of YHWH is in the Old Testament. Later chapters of the gospel give the name of Jesus particular significance in relation to the practices of prayer: requests made "in my name" $(14: 13,14 ; 15: 16 ; 16: 23,24,26)$ will answered by God. The name here has a certain mediatorial significance that is effectively inverted in the references to the Spirit being sent in the name of Jesus (14:26):

But the Advocate, the Holy Spirit, whom the Father will send in my name, will teach you everything, and remind you of all that I have said to you.

${ }^{34}$ Boyarin, "Gospel of the Memra," deals sensitively with the personification of Wisdom in the Jewish traditions and the backgrounds these provide to the imagery of personal presence in John 1:14. I cannot see any parallels, though, to the human particularity of Jesus in the Fourth Gospel. Personification is one thing; particular humanity is another.

${ }^{35}$ Joshua Coutts, “'My Father's Name': The Significance and Impetus of the Divine Name in the Fourth Gospel,' (Ph.D Dissertation, University of Edinburgh, 2016), 1. 
A complex association, then, is established between the name of Jesus and the name of God: on one hand, the name of Jesus is treated in terms that correspond to trusting in the name of YHWH, while on the other hand, it plays a distinctive mediatorial function in the human act of prayer and in the divine act of sending. All of this reaches a climax in John 17, with two paired statements that Jesus has made the name of God known to his disciples, between which is encountered another two paired references to the name being given to him:

I have made your name known to those whom you gave me from the world. They were yours, and you gave them to me, and they have kept your word. John 17:6.

And now I am no longer in the world, but they are in the world, and I am coming to you. Holy Father, protect them in your name that you have given me, so that they may be one, as we are one. While I was with them, I protected them in your name that you have given me. I guarded them, and not one of them was lost except the one destined to be lost, so that the scripture might be fulfilled. John $17: 11-12$.

I made your name known to them, and I will make it known, so that the love with which you have loved me may be in them, and I in them. John 17:26.

These occurrences of the word ovo $\mu \alpha$ constitute the final cluster in which the word is used of either Jesus or God and it is not inappropriate to see them as drawing to a climax the elements that have been developed through the gospel to this point. It is worth noting the apocalyptic or revelatory quality in 17:6 and 17:26. It is also worth noting the likely allusion to Isaiah 52:6 that these verses constitute:

Is. 52:6 Therefore my people shall know my name; therefore in that day they shall know that it is I who speak; here am I.

\section{לכן ידע עמי שמי לכן ביום ההוא כי אני הוא המדבר הנני 52:6.}

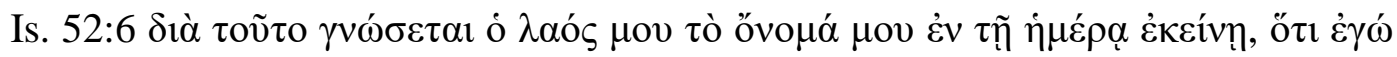

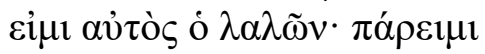

The pattern of references to the name of Jesus and the name of God reaches its climax אני הוא with an allusion to one of the passages in which we encounter a predicated statement, and this is, at the very least, suggestive of the connection between the name christology of the gospel and the $\dot{\varepsilon} \gamma \omega \dot{~ \varepsilon i \mu l ~ s a y i n g s . ~}$

This grounds all discussion of Johannine soteriology. The soteriological account that is subsequently unpacked in the gospel, in which people are saved by the one who explicates himself by the "I am" sayings, is traced back not merely to creation and fall, but to the perfection of the divine fullness in its inner relations. As well as recasting its details in general, this draws fresh attention to its trajectory, which is towards the involvement of its beneficiaries in those relations: when Jesus indicates that he has come that his people might have "life to the full" (John 10:10), he points forward to the life that is subsequently defined as knowing God and sharing in the 
fellowship that is internal to the Trinity (17:3, 21-23). The density of "name" language in this latter passage should not be overlooked: the participation in view is one of personal communion.

\section{The "I Am" Sayings in John}

Having surveyed these key backgrounds and contexts, we now finally turn to the $\dot{\varepsilon} \gamma \omega$. eiju sayings in John. My intention here is not to look at each of these in detail, but rather to isolate some of the ways in which specific sayings draw upon the themes we have just noted in the background texts and contexts. These allow us to see ways by which the sayings - considered as a set - may render the identity of Jesus with respect to God and the temporal cosmos.

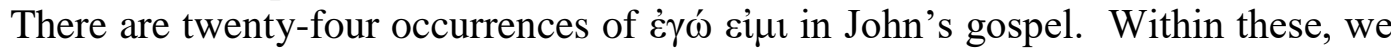
normally identify seven predicated sayings, ${ }^{36}$ counting the duplicated sayings as one (notably, "I am the bread of life," which occurs in three variant forms). ${ }^{37}$ This allows us to relate the seven sayings to other literary devices in the text that use a sevenfold pattern, particularly the signs. In truth, there are two further non-absolute sayings in 8:23 that may added to this list: "I am from above" and "I am not of this world." These, however, are formally distinct from the other sayings in that the $\dot{\varepsilon} \gamma \omega$ and the ciju are separated:

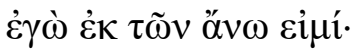

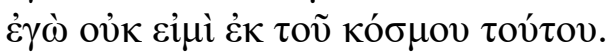

Despite this formal distinction, the two sayings in 8:23 provide a helpful entry point into considering the predicated statements because they stress the pre-existence of Jesus; more precisely, they emphasize that the speaker enjoyed a heavenly existence prior to and independent of his earthly one. In the terms that we noted in our discussion of the Prologue, the incarnation is represented as involving a movement, from outside the cosmos and outside time to inside these realities. His existence, in other words, is not contingent upon earthly matter or upon his emergence within the flow of time. The latter is, instead, contingent upon the former.

This same logic emerges in the first and most extensively developed of the predicated sayings, that concerning Jesus as the bread of life: "I am the (living) bread that came down from heaven" $(6: 41,51)$. In this context, too, we have an explanation for the movement:

36 "I am the bread of life," $6: 35,41,48,51$; "I am the light of the world," 8:12; "I am the door of the sheep," 10:7, 9; "I am the good shepherd," 10:11, 14; "I am the resurrection and the life," 11:25; "I am the way, and the truth, and the life," 14:6; "I am the true vine," 15:1, 5 .

${ }^{37}$ John 6:33: For the bread of God is that which comes down from heaven and gives life to the world. John 6:35: Jesus said to them, "I am the bread of life. Whoever comes to me will never be hungry, and whoever believes in me will never be thirsty" (cf also John 6:48, I am the bread of life). John 6:51, "I am the living bread that came down from heaven. Whoever eats of this bread will live forever; and the bread that I will give for the life of the world is my flesh." 
I have come down from heaven, not to do my own will, but the will of him who sent me (6:38)

While this could be read in subordinationist terms, it is more valuable to recognize that it grounds the descent, the involvement with creation, in the Son's loving service of the Father. The incarnation is an outreaching of the love that is internal to the life of God. This grounds the exclusivity of the identification that is replicated in all of the

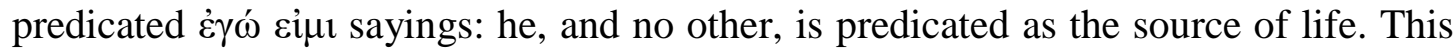
series of exclusive identifications specifically begins with one in which the pretemporal relationship with the Father is stressed, and not just pre-existence.

The temporal significance of the bread of life saying is not confined to preexistence. More subtly, as John deploys the saying, he also uses temporal language to indicate the permanent and inexhaustible character of the life that he, as the bread of life, is able to provide. His capacity to provide sustenance and satisfaction is not eroded or consumed over time and is, therefore, represented as something that is not contingent on the frailties of his creaturely existence. Rather, it participates in the perfect, eternal fullness of God:

The one who comes to me shall not hunger, the one who believes in me shall never thirst (6:35).

The last clause echoes the promise of living water that was made to the Samaritan woman in John 4:10,13 and 14. The use of the cognate verbal and nominal forms $\zeta \tilde{\omega} v$ and $\zeta \omega \eta$, applied both to the bread and the water, binds the images further. What is important to note is that both passages represent the life that is found in Jesus as not subject to the normal declines or fluctuations of time. Importantly, the fact that this is

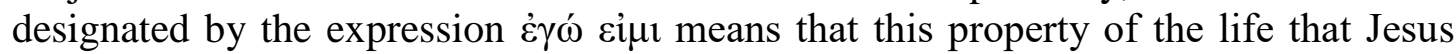
shares with others is understood to be a function of his own being, rather than simply a property that he mediates from another source (i.e., from a God considered other). He was, is, and will be the source of sustenance and satiety.

The same emphasis arises in the second of the sayings, "I am the light of the world" (8:12, 9:5). Once again, Jesus negates any suggestion of limitation or deterioration in his capacity to share light:

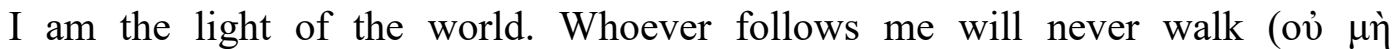
$\pi \varepsilon \rho \iota \pi \alpha \tau \eta \dot{\sigma \eta \eta})$ in darkness but will have the light of life.

The linking of light and life takes us back to both the Prologue and to John 5:26:

In him was life, and the life was the light of all men.

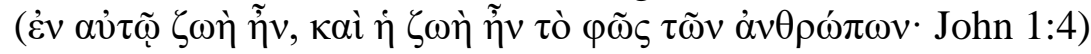

For just as the Father has life in himself, so he has granted the Son also to have life

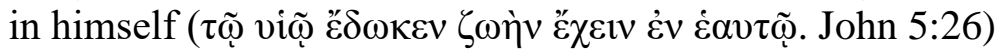

These are some of the key texts that have grounded the theological traditions around the aseity of the Son. It is important not to allow discussions of potential subordination within the Godhead (i.e., that grapple with what is signified by the Father's "giving to have life") to obscure the key detail that the Son's life is "in 


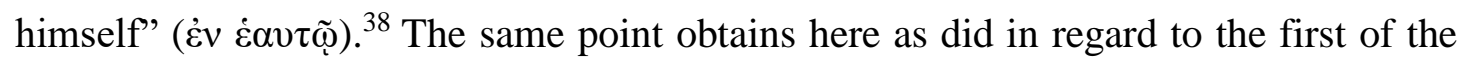
sayings: the Son does not mediate a life that is derived from another source, but is himself the light of the world. All of these themes converge in John 14:6- "I am the way, the truth and the life" - and in the final saying of 15:1 and 15:5_ "I am the vine ... apart from me you can do nothing."

This positive claim to be the one who shares a life that is a se is wrapped up, in the Fourth Gospel with the concept of resurrection. In the immediate context of John 5:26, the Gospel speaks of the dead hearing the voice of the Son of Man and coming forth from their graves $(5: 25,28-9)$, an image that is enacted in the story of Lazarus, where we encounter another of the $\dot{\varepsilon} \gamma \omega \dot{~ \varepsilon i \mu l ~ s a y i n g s: ~}$

I am the resurrection and the life. Those who believe in me, even though they die, will live, and everyone who lives and believes in me will never die. (John 11:25)

Again, by depicting resurrection not just as something Jesus gives or mediates from a separate source, but as something he is, the text demands that the resurrection of Lazarus is understood to be a participation in Jesus' own resurrection; like Jesus, he will live even though he dies. For the attentive reader of the Gospel, this invites

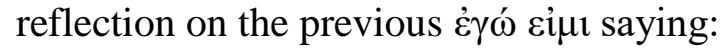

I am the Good Shepherd. The good shepherd lays down his life for the sheep (10:11, cf. 10:14-15).

No one takes [my life] from me, but I lay it down of my own accord. I have power to lay it down, and I have power to take it up again $(10: 18)$.

Having detected the significance of aseity in the language of the other $\varepsilon \gamma \omega \dot{~ \varepsilon i \mu t ~}$ sayings, we can see more clearly that the text grounds hope in the resurrection in the self-subsistent life of God. The cross is fundamentally contextualised by how its reality relates to the reality of the one being crucified: if the sheep are to be saved, the Shepherd must lay down his life, but he can do so redemptively because he has in himself the authority to take it up again. His death is not the terminal point of his narrative, and precisely because of this it opens the hope of resurrection, of a story that continues beyond termination, to those who will hear his voice and will abide in his life. The key soteriological move in the gospel is that the Son willingly accommodates himself to the strictures of time and space in his act of enfleshment. He is not impervious to the effects of these while incarnate, but, as the one whose life is inherent to his own being (and thus not contingent upon the fate of the flesh that he assumes or becomes), he is able to lay down that life and to take it up again.

There are subtle points of language to which we must be attentive. Bauckham, drawing on Moltmann, is surely in line with Johannine thought when he sees the redemptive significance of the cross as a function of its inalienable connection to the

${ }^{38}$ For this point, and its significance to theological readings such as those of Augustine, see Webster, "Life in and of Himself," 25. Webster's argument is developed in Ellis, Calvin, Classical Trinitarianism and the Aseity of the Son, 197226. The link between John 5:26 and the "I am" sayings that I trace here might be taken as a support of the particularly strong account of the Son's aseity that Webster and Ellis, drawing on Calvin, develop. 
resurrection, itself a function of its incorporation into the narrative of the trinitarian life:

The resurrection is God's promise of liberation from suffering for all those with whom Christ is identified in his cross, the godless and the godforsaken. In the cross all human suffering is taken within God's own "trinitarian history" in hope for the joy of God's eschatological future. ${ }^{39}$

For John, though, this functional reality proceeds from the most basic ontological reality of divine aseity and this demands that any use of the language of "history" is carefully qualified. Arguably Jüngel's way of framing the redemptive union of the contingent and the non-contingent, in terms of the divine being "als Auch-sichheraus-Gehen in das Nichts" 40 is closer to what we see in John's Gospel, here and elsewhere. ${ }^{41}$ To speak without such qualifications of the cross becoming part of trinitarian history runs the risk of describing only the functional realities that are visible from within the created order. But those realities are grounded in the ontology of the incarnation itself, by which the one who is God of himself, of himself gave himself.

\section{Conclusions}

The Fourth Gospel introduces Jesus as the one who will make God known (1:18), and biblical scholarship must be attentive to the properly theological significance of this; according to the Gospel, talk of God, in himself, must be informed by the reality of the incarnation. The representation of Jesus in the Gospel draws upon a stock of coordinated traditions associated with the divine identity and attributes, particularly the divine name and the $\dot{\varepsilon} \gamma \omega \dot{\omega}$ אני הוא/ sayings. Within the biblical and Jewish literature, these distinct traditions are interwoven around the concept of divine aseity,

${ }^{39}$ Richard Bauckham, "Only the Suffering God Can Help: Divine Passibility in Modern Theology," Themelios 9 (1984), 12, drawing on Jürgen Moltmann, The Crucified God: The Cross of Christ as the Foundation and Criticism of Christian Theology (London: SCM, 1974), 278.

${ }^{40}$ Gott als Geheimnis, 303.

${ }^{41}$ A similar play on the temporal significance of the divine name seems to be at work

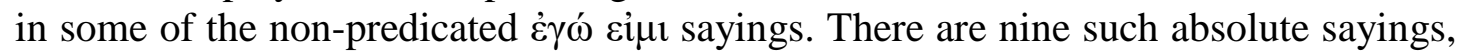

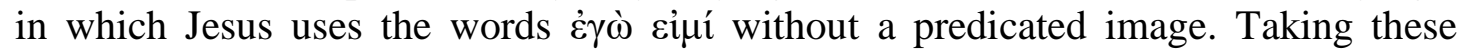
together with the 7 predicated saying, some of which are repeated several times, gives us the figure of 24, noted earlier. In most cases, the non-predicated sayings tend to be translated (quite defensibly) as "I am he." In terms of this article, the most obviously relevant of these sayings is that of John 8:58: "Before Abraham was, I am" ( $\pi$ piv

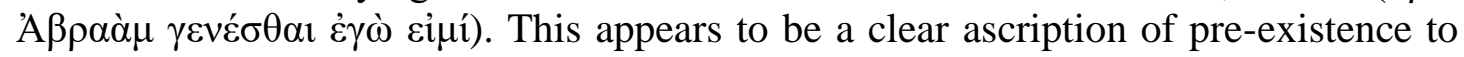
Jesus and one that triggers an attempt to stone him for blasphemy. This cannot simply be a matter of the claim to pre-existence, since this might be made without claiming to be God; rather, the blasphemy is constituted by the way in which that claim is made, that is, by appropriating the divine self-designation $\dot{\varepsilon} \gamma \omega \dot{\varepsilon} \dot{\jmath} \mu$. 
which is not reducible to the notions of eternity or non-contingency, but is a more positive concept that labels divine self-subsistence: 'God is from himself, and from himself God gives himself', ${ }^{42}$

The Gospel, from its opening line, represents the Son as participating in the inner relations of God and, as a consequence of this, in God's unique relationship to time: he is not simply (in our terms) pre-existent, but is $\pi \rho \tilde{\omega} \tau$ ó $\zeta$, being with God $\dot{\varepsilon} v \dot{\alpha} \rho \chi \tilde{\eta}$. The origins and the ends of the cosmos derive their life from the underived fullness of God, now understood in incipiently trinitarian terms, and the arc of Johannine soteriology must be plotted in terms of such reference points: the one who has life in himself has come that others might share that life, by sharing in the eternal fellowship of the Godhead (17: 3, 21-23). In its representation of incarnation, the Gospel applies spatial language with what must therefore be seen to have both temporal and relational implications: 'the Word became flesh and dwelt among us' designates a new condition in which the God who is outside time enters it in such a way to make temporal and geographical locatedness part of his own identity, with salvific purpose.

Crucially, the Gospel proceeds to coordinate the name of the one who is so temporally and geographically located with the name of God himself: the name of Jesus and the name of YHWH are now identified. Given that this name has intrinsic associations with aseity, reflected in the biblical and Jewish traditions, the move sustains the concept and allows it to become part of the incarnational account; that he is temporally and geographically located in flesh does not negate the fact that he is $a$ $s e$, for the Son has life in himself (5:26). Instead, his aseity in union with his humanity becomes the basis for salvation. He can lay down his life and take it up again, he can nourish and satiate without limit or deterioration, he can lead others into the fellowship that existed before the cosmos because he is a se, and because, as such, he can engage in such relations with the created world without the normal expectations of mortality or deterioration applying. Johannine soteriology, then, is distinctively shaped by the ontology of the incarnation: it is not just what Jesus does, but what or who he is that determines the shape and course of salvation. Salvation is grounded in

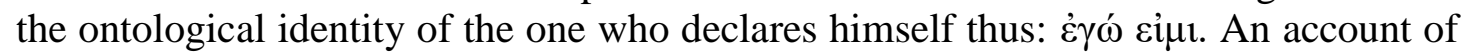
christology that fails to reckon with this properly theological ontology is deficient, at least with respect to what we find in the Fourth Gospel. ${ }^{43}$ At the same time, an account of theology proper that renders aseity merely in terms of non-contingency, and does not complete the statement that "God is from himself" with "from himself God gives himself," falls short of the Fourth Gospel's recasting of the divine identity.

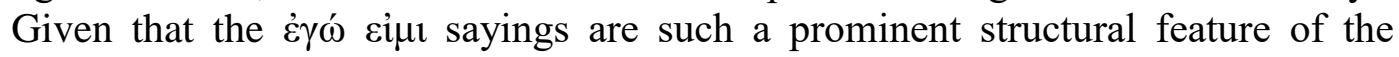
Fourth Gospel, and given, too, the connections we have seen with the Prologue, a final point can be made. What we have outlined in this article is not a minor or peripheral strand in Johannine soteriology, a strange trace of Hellenistic metaphysics that could easily be excised from the narrative; rather, it is one of the key elements in John's account of salvation. Johannine scholarship should be more attentive to it, and to its structuring role in the Gospel as a whole. In turn, this speaks to contemporary theology, issuing a reminder that ontological issues cannot be bypassed in our talk of the God who names himself, "I am."

\footnotetext{
${ }^{42}$ Webster, "Life in and of Himself," 19.

${ }^{43}$ The importance of affirming divine ontology in relation to the incarnation is emphasized in John Webster's later theology. See Michael Allen, "Toward Theological Anthropology: Tracing the Anthropological Principles of John Webster," International Journal of Systematic Theology 19 (2017), 6-29, see esp. p.18.
} 
